\title{
Reclassification of Rhizobium tropici type A strains as Rhizobium leucaenae sp. nov.
}

\author{
Renan Augusto Ribeiro, ${ }^{1,2} \dagger$ Marco A. Rogel, ${ }^{3} \dagger$ Aline López-López, ${ }^{3}$ \\ Ernesto Ormeño-Orrillo, ${ }^{1}$ Fernando Gomes Barcellos, ${ }^{4}$ Julio Martínez, ${ }^{3}$ \\ Fabiano Lopes Thompson, ${ }^{5}$ Esperanza Martínez-Romero ${ }^{3}$ \\ and Mariangela Hungria ${ }^{1}$ \\ ${ }^{1}$ Embrapa Soja, Cx. Postal 231, 86001-970, Londrina, Paraná, Brazil \\ ${ }^{2}$ Universidade Estadual de Londrina, Department of Microbiology, Cx. Postal 60001, 86051-990, \\ Londrina, Paraná, Brazil \\ ${ }^{3}$ Centro de Ciencias Genómicas, Universidad Nacional Autónoma de México, Cuernavaca, Morelos, \\ Mexico \\ ${ }^{4}$ Universidade Paranaense - UNIPAR, Cx. Postal 224, 87502-210, Umuarama, Paraná, Brazil \\ ${ }^{5}$ UFRJ, Center of Health Sciences, Institute of Biology, Cx. Postal 68011, 21944-970, \\ Rio de Janeiro, Brazil
}

Correspondence

Ernesto Ormeño-Orrillo eormeno.orrillo@gmail.com

Rhizobium tropici is a well-studied legume symbiont characterized by high genetic stability of the symbiotic plasmid and tolerance to tropical environmental stresses such as high temperature and low soil $\mathrm{pH}$. However, high phenetic and genetic variabilities among $R$. tropici strains have been largely reported, with two subgroups, designated type $A$ and $B$, already defined within the species. A polyphasic study comprising multilocus sequence analysis, phenotypic and genotypic characterizations, including DNA-DNA hybridization, strongly supported the reclassification of $R$. tropici type A strains as a novel species. Type A strains formed a well-differentiated clade that grouped with $R$. tropici, Rhizobium multihospitium, Rhizobium miluonense, Rhizobium lusitanum and Rhizobium rhizogenes in the phylogenies of the $16 \mathrm{~S} r \mathrm{RNA}, r e c A, g / t A, r p o A, g / n / l$ and $r p o B$ genes. Several phenotypic traits differentiated type A strains from all related taxa. The novel species, for which the name Rhizobium leucaenae sp. nov. is proposed, is a broad host range rhizobium being able to establish effective root-nodule symbioses with Leucaena leucocephala, Leucaena esculenta, common beans (Phaseolus vulgaris) and Gliricidia sepium. Strain CFN $299^{\top}\left(=\right.$ USDA $9039^{\top}=$ LMG $9517^{\top}=$ CECT $4844^{\top}=\mathrm{JCM} 21088^{\top}=$ IAM $14230^{\top}=\mathrm{SEMIA}$ $4083^{\top}=$ CENA $183^{\top}=$ UMR $1026^{\top}=$ CNPSo $141^{\top}$ ) is designated the type strain of Rhizobium leucaenae sp. nov.

A group of bacterial species, collectively known as rhizobia, can induce the formation of specific structures, named nodules, on the roots of legumes eliciting a symbiotic process in which the rhizobia fix atmospheric nitrogen and supply it to the plant. Interest in the use of rhizobia as biofertilizers in agriculture has promoted studies on their diversity and the description of a large number of rhizobial species. Rhizobium tropici is a broad host range rhizobial species that was isolated from Leucaena spp. nodules in

†These authors contributed equally to this work.

The GenBank/EMBL/DDBJ accession numbers for the 49 sequences reported in this paper are provided in Table S1 (available in IJSEM Online).

Five supplementary tables and seven supplementary figures are available with the online version of this paper.
Brazil (Hungria et al., 2000; Martínez-Romero et al., 1991), and from Gliricidia sepium (Acosta-Durán \& MartínezRomero, 2002) and Acaciella angustissima (Rincón-Rosales et al., 2009) in Mexico. The species has also been isolated from common bean (Phaseolus vulgaris) nodules in several countries (Amarger et al., 1994; Anyango et al., 1995; Diouf et al., 2000; Grange \& Hungria, 2004; Pinto et al., 2007). R. tropici has been used as an efficient inoculant for beans in the tropics, due to its high tolerance to environmentally stressful conditions and its high genetic stability (Hungria et al., 2000, 2003).

R. tropici, reported in 1991 (Martínez-Romero et al., 1991), was the first description of a rhizobial species to include $16 \mathrm{~S}$ rRNA gene sequence analysis. At that time, in spite of evidence that supported the proposal of two species from 
the nodule isolates analysed, e.g. differences in $16 \mathrm{~S}$ rRNA gene sequences and low DNA-DNA hybridization values, only one novel species was accepted. However, two types, $\mathrm{A}$ and $\mathrm{B}$, were recognized to account for these differences. Other species are now recognized to be close relatives of $R$. tropici, such as Rhizobium lusitanum (Valverde et al., 2006), Rhizobium multihospitium (Han et al., 2008), Rhizobium miluonense ( $\mathrm{Gu}$ et al., 2008) and Rhizobium rhizogenes (Hernández-Lucas et al., 2004; Velázquez et al., 2010). Some of these species are either more closely related to type A or to type B strains in phylogenetic trees (Han et al., 2008; Valverde et al., 2006; Velázquez et al., 2010). Recently, it was recommended that species containing several distinct genotype clusters should be subdivided into multiple species, each corresponding to a single genotype cluster (Achtman \& Wagner, 2008). In this study, we review reported differences between the two $R$. tropici groups and present new evidence to suggest that $R$. tropici type A strains belong to a novel species that is distinct from R. tropici.

The rhizobial strains used in this study are listed in Table S2 (available in IJSEM Online). Four Brazilian strains (BR 828, BR 10043, CPAO 29.8, 77) were chosen as representatives of a large collection of strains identified as $R$. tropici type $\mathrm{A}$ in previous studies (Grange \& Hungria, 2004; Martínez-Romero et al., 1991; Mercante et al., 1998; Pinto et al., 2007). The well-studied strain CFN $299^{\mathrm{T}}$ from the type A subgroup was also included and proposed as the type strain of the novel species. Three previously unreported Mexican isolates (CCGE 521, CCGE 522, CCGE 523) obtained from Zacatecas, the largest common-bean-growing area in Mexico, were also included. All strains were deposited at the 'Diazotrophic and Plant Growth Promoting Bacteria Culture Collection' of Embrapa Soja (Londrina, Brazil), and at the Center for Genomic Sciences Culture Collection (Cuernavaca, Mexico). Except where specified, strains were grown on yeast extract-mannitol (YM) broth [as Vincent (1970), except with a mannitol concentration of $5 \mathrm{~g} \mathrm{l}^{-1}$ ] in the dark, at $28^{\circ} \mathrm{C}$. Source cultures were maintained in YM agar (YMA) at $4{ }^{\circ} \mathrm{C}$. Stocks were prepared on $\mathrm{YM}$ and kept at $-80{ }^{\circ} \mathrm{C}$ (in $30 \%$ glycerol) for long-term storage.

Total genomic DNA of each strain was extracted as described before (Kaschuk et al., 2006). Repetitive extragenic palindromic-PCR genomic fingerprints with the BOX-A1R primer were generated and analysed as described by Pinto et al. (2007). Genomic fingerprints revealed a group of four Brazilian and three Mexican strains that clustered with CFN $299^{\mathrm{T}}$, the reference type A strain. This cluster was clearly separated from R. tropici type B (Fig. S1, available in IJSEM Online) as well as from other rhizobial type or reference strains (data not shown). In a previous study, Brazilian type A strains CFN $299^{\mathrm{T}}$, CPAO 29.8 and 77 also clustered separately from $R$. tropici type B in a combined analysis of REP, ERIC and BOX-A1R fingerprints (Pinto et al., 2007).
Besides the 16S rRNA gene phylogeny, a multilocus sequence analysis approach with five protein-coding genes was used to establish the relationships between type A strains and related taxa. Near full-length $16 \mathrm{~S}$ rRNA gene and fragments of recA, gltA, rpoA, glnII and $r p o B$ were amplified and sequenced as described previously (Ribeiro et al., 2009; Rincón-Rosales et al., 2009). All these genes have been used previously in studies of rhizobial diversity (Martens et al., 2007; Ribeiro et al., 2009; Rincón-Rosales et al., 2009). Multiple sequence alignments were performed with CLUSTAL_X version 1.83 (Thompson et al., 1997) and manually checked with BioEdit (Hall, 1999). Best-fit models of sequence evolution were selected for each gene, and for the concatenated set of five protein-coding genes with JModelTest 0.1.1, using the Akaike information criterion (Posada, 2008). Maximum-likelihood phylogenies were constructed with PhyML 3 using subtree pruning and regrafting moves to improve tree topology (Guindon et al., 2010). Support for tree nodes was evaluated by the Shimodaira-Hasegawa-like approximate likelihood-ratio test implemented in PhyML.

R. tropici type A strains formed a well-supported clade in the 16S rRNA gene phylogeny and, together with $R$. lusitanum, $R$. rhizogenes, $R$. tropici type B, R. multihospitium and $R$. miluonense, constituted a group of closely related species, hereby designated the ' $R$. tropici group' (Fig. 1). The $16 \mathrm{~S}$ rRNA gene sequences of type A strains showed $\geqslant 99.8 \%$ identity to each other and $\leqslant 99.4 \%$ identity with other strains in the ' $R$. tropici group' (Table S3, available in IJSEM Online). Willems \& Collins (1993) described an insertion of 72 nucleotides in the $\mathrm{V} 1$ region of the 16S rRNA gene of strain CFN $299^{\mathrm{T}}$. Later, it was confirmed that the insertion was present in several type A but not in type B strains (Hungria et al., 2000; van Berkum et al., 1994). In this study, presence of the insertion was confirmed in the Brazilian type A strains CPAO 29.8, 77, BR 10043 and BR 828, and also in the Mexican strains CCGE521, CCGE522 and CCGE523. The insertion was absent in all available sequences from the Rhizobium type strains with a complete $\mathrm{V} 1$ region sequenced. Thus, the $72 \mathrm{bp}$ insertion seems to be a characteristic of type A strains. Another genetic difference in the ribosomal operon between type A and type B strains was highlighted in a study by Pinto et al. (2007), in which strains CFN $299^{\mathrm{T}}$, CPAO 29.8 and 77 showed similar profiles in the amplified rRNA gene restriction analysis of the $23 \mathrm{~S}$ rRNA and were separate from the cluster including R. tropici CIAT $899^{\mathrm{T}}$.

Nucleotide similarities between type A strains and other species of the ' $R$. tropici group' were less than 94.0, 98.7, 97.2, 93.9 and $94.4 \%$ for the recA, gltA, rpoA, glnII and $r p o B$ genes, respectively. Except for $R$. multihospitium (recA) and $R$. lusitanum ( $g l t A)$, similarities among type A strains were higher than between this group and the other species (Table S3). Type A sequences formed wellsupported clades that differed from those containing type B and other species sequences in all single gene phylogenies (Figs S3-S7). In the phylogeny constructed with the 


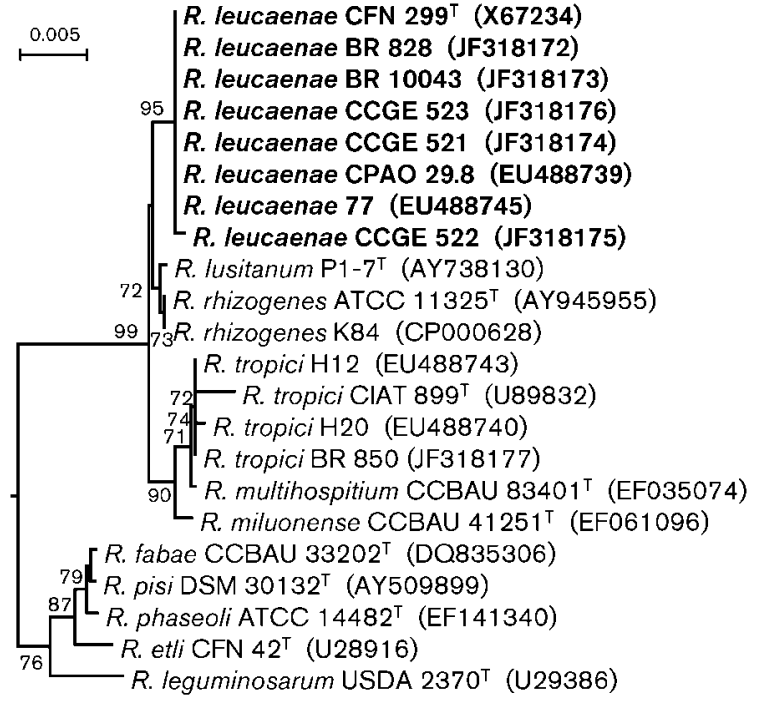

Fig. 1. Part of a maximum-likelihood phylogeny of the $16 \mathrm{~S}$ rRNA gene showing the relationships between Rhizobium leucaenae strains (in bold) and other type or reference strains from closely related species (the complete phylogeny containing a larger number of reference sequences is available as Fig. S2). GenBank accession numbers are shown in parentheses. Only node supports higher than $70 \%$ are shown. Bar, 5 nt substitutions per 1000 nt.

concatenated alignments (Fig. 2), the type A strains formed a sister clade to a highly supported group containing $R$. tropici type $\mathrm{B}, R$. multihospitium and $R$. miluonense. $R$. lusitanum occupied an intermediate position between the above species and $R$. rhizogenes, with the latter being the basal species in the ' $R$. tropici group'.

DNA-DNA hybridizations were used to determine the DNA relatedness among type A strains and between this group and the type species of related taxa. A previously described filter hybridization methodology (MartínezRomero et al., 1991) using ${ }^{32}$ P-labelled DNA of strain CFN $299^{\mathrm{T}}$ as a probe was used. Type A strains shared high levels of DNA-DNA relatedness $(\geqslant 78.8 \%)$. Strain CFN $299^{\mathrm{T}}$ showed $45.5,37.5,38.2,33.2$ and $28.7 \%$ hybridization values with $R$. lusitanum $\mathrm{P} 1-7^{\mathrm{T}}, R$. miluonense CCBAU $41251^{\mathrm{T}}, R$. tropici CIAT $899^{\mathrm{T}}, R$. multihospitium CCBAU $83401^{\mathrm{T}}$ and $R$. rhizogenes IAM $13570^{\mathrm{T}}$, respectively. These data are consistent with the previously reported $39 \%$ DNA-DNA hybridization value between CFN $299^{\mathrm{T}}$ and CIAT $899^{\mathrm{T}}$ (Martínez-Romero et al., 1991), which is below the threshold for species definition (Coenye et al., 2005; Vandamme et al., 1996). Other studies have also shown low DNA-DNA hybridization values between CFN $299^{\mathrm{T}}$ and strains belonging to the ' $R$. tropici group' (Gu et al., 2008; Han et al., 2008; Valverde et al., 2006). All these data support the differentiation of type A strains from all the species in the ' $R$. tropici group'.

The DNA $\mathrm{G}+\mathrm{C}$ contents of three type A strains were estimated according to Moreira et al. (2011). Vibrio

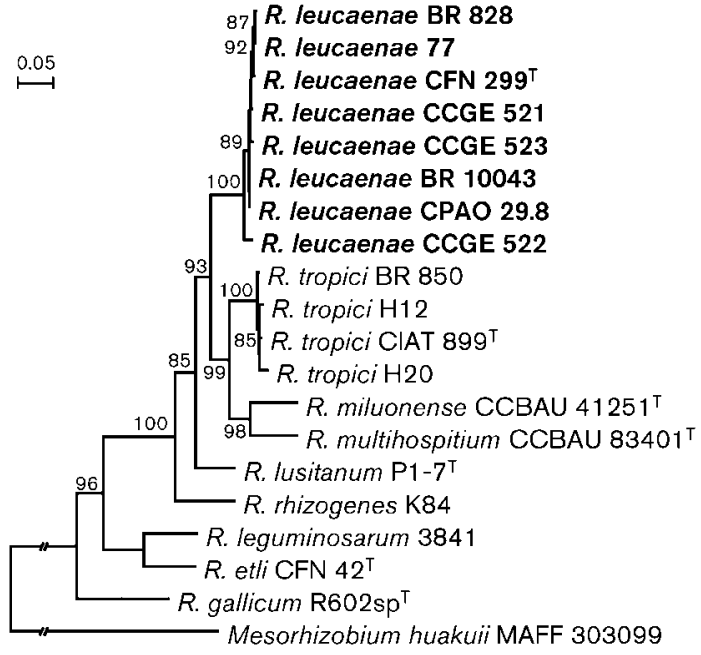

Fig. 2. Maximum-likelihood phylogeny of five concatenated protein-coding genes $(r e c A+g l t A+r p o A+g l n l l+r p o B)$ showing the relationships between Rhizobium leucaenae strains and other type or reference strains from closely related species. GenBank accession numbers for each gene and strain are given in Table S1. Only node supports higher than $80 \%$ are shown. Bar, $5 \mathrm{nt}$ substitutions per 100 nt.

furnissii CAIM $518^{\mathrm{T}}$ was included as a control; the reported DNA G + C content for this strain is $50.4 \mathrm{~mol} \%$ (Brenner et al., 1983). The analyses were performed at least twice using six replicates in each experiment. The DNA G+C contents of strains CFN299 ${ }^{\mathrm{T}}$, CPAO 29.8 and CCGE 522 were $64.1,63.5$ and $63.6 \mathrm{~mol} \%$, respectively, which are within the range reported for Rhizobium species. The fatty acid profile of the representative type A strain CFN $299^{\mathrm{T}}$, grown for $48 \mathrm{~h}$ on YMA (Vincent, 1970) plates, was determined with the MIDI system using the TSBA6 database. The results obtained (Table S5, available in IJSEM Online) further confirmed the affiliation to the Rhizobium genus as common fatty acids found in this genus (Tighe et al., 2000) were also observed in CFN $299^{\mathrm{T}}$.

Morpho-physiological characterization of the strains included evaluation of colony morphology, acid/alkaline production in YMA, tolerance to various $\mathrm{pH}$ and temperature conditions, growth in Luria-Bertani (LB) and peptone-yeast extract (PY) without $\mathrm{Ca}$ media, as described previously (Hungria et al., 2000; MartínezRomero et al., 1991). Growth on selected carbon and nitrogen sources was evaluated as described previously (Martínez-Romero et al., 1991). In addition, bacteria were evaluated for the capacity to utilize the 49 carbohydrates included in the API 50CH kit (bioMérieux) as specified by the manufacturer, using YM-minus-mannitol as the basal medium. Resistance to chloramphenicol $\left(50 \mu \mathrm{g} \mathrm{ml}^{-1}\right)$ and kanamycin sulfate $\left(5 \mu \mathrm{g} \mathrm{ml}^{-1}\right)$ in YMA, and to captan $\left(50 \mu \mathrm{g} \mathrm{ml}^{-1}\right)$ and thiram $\left(25 \mu \mathrm{g} \mathrm{ml}^{-1}\right)$ in PY agar plates was also evaluated. Captan and thiram are seed-dressing 
Table 1. Distinctive phenotypic features of Rhizobium leucaenae sp. nov. and phylogenetically related species

Taxa: 1, R. leucaenae (former $R$. tropici type A); 2, R. tropici (former $R$. tropici type B); 3, R. lusitanum; 4, R. multihospitium; $5, R$. miluonense; $6, R$. rhizogenes. +, Growth, -, no growth; w, weak growth; ND, not determined. Data obtained in this study or compiled from the original studies describing the species, or from Amarger et al. (1997), Bouzar et al. (1993), and Sawada \& Ieki (1992). Only characteristics with consistent data between studies were included.

\begin{tabular}{|c|c|c|c|c|c|c|}
\hline Characteristic & 1 & 2 & 3 & 4 & 5 & 6 \\
\hline \multicolumn{7}{|c|}{ Utilization as sole carbon source } \\
\hline Sodium acetate & - & - & + & - & - & - \\
\hline D-Amygdalin & + & - & + & + & + & + \\
\hline DL-Arginine & - & - & - & + & + & - \\
\hline DL-Aspartic acid & - & - & + & + & - & - \\
\hline Erythritol & - & + & + & + & + & + \\
\hline Sodium formate & - & - & - & + & - & - \\
\hline Glycine & - & - & + & - & - & - \\
\hline Inulin & - & - & + & - & - & - \\
\hline Malate & - & + & + & + & + & ND \\
\hline Melezitose & - & - & + & - & - & + \\
\hline DL-Proline & - & - & + & + & - & - \\
\hline Sodium pyruvate & + & + & + & + & + & - \\
\hline Sorbose & + & - & + & + & + & - \\
\hline \multicolumn{7}{|c|}{ Utilization as sole nitrogen source } \\
\hline D-Threonine & - & - & - & + & - & - \\
\hline L-Threonine & - & - & - & + & + & - \\
\hline \multicolumn{7}{|l|}{ Growth in/at: } \\
\hline PY without $\mathrm{Ca}$ & - & + & + & + & + & + \\
\hline LB & - & + & + & + & - & - \\
\hline $37{ }^{\circ} \mathrm{C}$ & + & + & + & + & + & - \\
\hline $40{ }^{\circ} \mathrm{C}$ & $\mathrm{w}$ & + & - & - & - & - \\
\hline $1 \% \mathrm{NaCl}$ & - & + & $\mathrm{w}$ & + & - & - \\
\hline $\mathrm{pH} 4$ & $\mathrm{w}$ & + & - & + & - & ND \\
\hline \multicolumn{7}{|l|}{ Resistance to $\left(\mu \mathrm{g} \mathrm{ml}^{-1}\right)$ : } \\
\hline Chloramphenicol (50) & - & + & $\mathrm{w}$ & + & - & - \\
\hline Kanamycin sulfate (5) & - & - & $\mathrm{w}$ & + & - & + \\
\hline
\end{tabular}

fungicides commonly used in agriculture and may influence the survival of seed-applied rhizobial inoculants.

All type A strains analysed in this study showed similar reactions in the morpho-physiological tests. Known traits distinguishing type A from type B strains first reported by Martínez-Romero et al. (1991) and further described by Hungria et al. (2000) and Pinto et al. (2007), such as colony morphology, antibiotic-resistance patterns, growth on LB or PY without Ca were confirmed (Table 1). $R$. tropici type $\mathrm{B}$ strains can tolerate $40{ }^{\circ} \mathrm{C}$, whereas type $\mathrm{A}$ strains grow very poorly at this temperature. Novel differences between the two groups were found in this study. Both strain types produce acid in YMA medium but only colonies from type A strains acquire a yellow colour when the medium is supplemented with bromothymol blue. Besides being more sensitive to several antibiotics than type B strains (Martínez-Romero et al., 1991), type A strains are also more sensitive to the fungicides captan and thiram (Table S4, available in IJSEM Online). Additionally, 15 out of the 49 tests in the API 50CH kit differentiated the strain types (Table S4).

In the description of $R$. tropici as a novel species, type A and $B$ strains formed well separated groups from data derived from multilocus enzyme electrophoresis analysis with eight metabolic enzymes (Martínez-Romero et al., 1991). The groups were separated at a genetic distance over 0.5 , which was used as the limit to distinguish species (Musser et al., 1987; Selander et al., 1985). Further analysis with glutamine synthetase II isoenzymes clearly distinguished type A and type B strains (Taboada et al., 1996). Megaplasmids of similar size (over $1700 \mathrm{~kb}$ ) were observed in both type A and type B strains but they were found to be subgroup-specific, indicating that type A and B strains belonged to different taxa (Geniaux et al., 1995). Such megaplasmids may correspond to chromids (E. OrmeñoOrrillo and others, unpublished results) as defined by Harrison et al. (2010), and should have taxonomic value in contrast to conjugative plasmids. Other differences, reported elsewhere, include a Hup (uptake hydrogenase)-positive phenotype of type A strains, whereas only a few type B strains showed this characteristic (van Berkum et al., 1994).

All differences in genetic and phenotypic properties between the type A and B strains of R. tropici reported in this and previous studies suggest that type A strains are members of a distinct species, for which the name Rhizobium leucaenae is proposed. This novel species can also be differentiated from other species of the ' $R$. tropici group' by sequence analysis, as mentioned previously, and by the phenotypic traits presented in Table 1 .

Based on data reported in previous works, $R$. leucaenae is present in several regions of Brazil (Grange \& Hungria, 2004; Martínez-Romero et al., 1991; Mercante et al., 1998; Pinto et al., 2007). Although these regions encompass a variety of ecosystems, $R$. leucaenae occurs abundantly in the Cerrados savannah, which occupies about $25 \%$ of Brazil. In that region, $R$. leucaenae represented $79 \%$ and $15 \%$ of the rhizobial population obtained using Leucaena leucocephala and common bean as trap hosts, respectively (Mercante et al., 1998). R. leucaenae has also been found in the state of Veracruz, Mexico, in nodules of Gliricidia sepium (AcostaDurán \& Martínez-Romero, 2002). In Zacatecas, the largest bean-growing area in Mexico, a low proportion (less than $10 \%$ ) of the nodule bacterial isolates from beans were identified as $R$. leucaenae based on analysis of $16 \mathrm{~S}$ rRNA or $r p o B$ gene sequences (our own unpublished results).

\section{Description of Rhizobium leucaenae sp. nov.}

Rhizobium leucaenae (leu.cae'nae. N.L. gen. n. leucaenae of Leucaena, referring to the isolation source of many strains of this species, root nodules of Leucaena).

Gram-negative, aerobic, non-spore-forming rods. Colonies on YMA medium are circular, flat, white, opaque, dry, with 
low to moderate production of mucus and usually 2 to $4 \mathrm{~mm}$ in diameter within 2 to 3 days of incubation at $28{ }^{\circ} \mathrm{C}$. Strains acidify the YMA medium after 3 days. Can tolerate $37{ }^{\circ} \mathrm{C}$ and grow weakly at $\mathrm{pH} \mathrm{4}$; however, optimum growth occurs at pH 5 to 7 and at 25 to $28{ }^{\circ} \mathrm{C}$. Strains do not grow in LB medium or PY minus Ca and are sensitive to chloramphenicol $\left(50 \mu \mathrm{g} \mathrm{ml}^{-1}\right)$ and kanamycin $\left(5 \mu \mathrm{g} \mathrm{ml}^{-1}\right)$. As sources of carbon, they use D-arabinose, Darabitol, cellobiose, D-fructose, D-galactose, D-glucose, sucrose, gluconate, maltose, D-lyxose, D-mannose, D-ribose, glycerol, L-arabitol, L-fucose, L-sorbose, mannitol and xylitol. Strains induce the formation of root nodules and fix $\mathrm{N}_{2}$ with L. leucocephala, Leucaena esculenta, G. sepium and Phaseolus vulgaris.

The type strain is CFN $299^{\mathrm{T}} \quad\left(=\mathrm{USDA} \quad 9039^{\mathrm{T}}=\mathrm{LMG}\right.$ $9517^{\mathrm{T}}=$ CECT $4844^{\mathrm{T}}=$ JCM $21088^{\mathrm{T}}=$ IAM $14230^{\mathrm{T}}=$ SEMIA $4083^{\mathrm{T}}=$ CENA $183^{\mathrm{T}}=$ UMR $1026^{\mathrm{T}}=$ CNPSo $141^{\mathrm{T}}$ ), isolated from an effective nodule of Phaseolus vulgaris in Brazil. The DNA G + C content of strain CFN $299^{\mathrm{T}}$ is $64.1 \mathrm{~mol} \%$.

\section{Acknowledgements}

The work was partially supported by $\mathrm{CNPq}$ (Conselho Nacional de Desenvolvimento Científico e Tecnológico, Brazil), MCT/MAPA (577933/2008), CNPq-Universal (470162/2009-0), Repensa (562008/ 2010-1) and PAPIIT 205412. R. A. R. acknowledges a PhD fellowship from Fundação Araucária (Paraná, Brazil) and M. H. acknowledges a researcher fellowship from $\mathrm{CNPq}(300698 / 2007-0)$. M. A. R. was a $\mathrm{PhD}$ student in the Ciencias Biológicas program at UNAM and received a fellowship from CONACYT. The laboratories have a bilateral project CNPq/CONACYT (490048/2009-9). The authors thank Ligia M. O. Chueire, Pâmela Menna and Jesiane S. Batista (Embrapa Soja) for help in several steps of this work. We acknowledge Manuel López-Muñoz and Jean P. Euzéby for their help in the creation of the specific epithet.

\section{References}

Achtman, M. \& Wagner, M. (2008). Microbial diversity and the genetic nature of microbial species. Nat Rev Microbiol 6, 431-440.

Acosta-Durán, C. \& Martínez-Romero, E. (2002). Diversity of rhizobia from nodules of the leguminous tree Gliricidia sepium, a natural host of Rhizobium tropici. Arch Microbiol 178, 161-164.

Amarger, N., Bours, M., Revoy, F., Allard, M. R. \& Laguerre, G. (1994). Rhizobium tropici nodulates field-grown Phaseolus vulgaris in France. Plant Soil 161, 147-156.

Amarger, N., Macheret, V. \& Laguerre, G. (1997). Rhizobium gallicum sp. nov. and Rhizobium giardinii sp. nov., from Phaseolus vulgaris nodules. Int J Syst Bacteriol 47, 996-1006.

Anyango, B., Wilson, K. J., Beynon, J. L. \& Giller, K. E. (1995). Diversity of rhizobia nodulating Phaseolus vulgaris L. in two Kenyan soils with contrasting pHs. Appl Environ Microbiol 61, 4016-4021.

Bouzar, H., Jones, J. B. \& Hodge, N. G. (1993). Differential characterization of Agrobacterium species using carbon-source utilization patterns and fatty acid profiles. Phytopathology 83, 733739.

Brenner, D. J., Hickman-Brenner, F. W., Lee, J. V., Steigerwalt, A. G., Fanning, G. R., Hollis, D. G., Farmer, J. J., III, Weaver, R. E., Joseph, S. W. \& Seidler, R. J. (1983). Vibrio furnissii (formerly aerogenic biogroup of Vibrio fluvialis), a new species isolated from human feces and the environment. J Clin Microbiol 18, 816-824.

Coenye, T., Gevers, D., Van de Peer, Y., Vandamme, P. \& Swings, J. (2005). Towards a prokaryotic genomic taxonomy. FEMS Microbiol Rev 29, 147-167.

Diouf, A., de Lajudie, P., Neyra, M., Kersters, K., Gillis, M., MartínezRomero, E. \& Gueye, M. (2000). Polyphasic characterization of rhizobia that nodulate Phaseolus vulgaris in West Africa (Senegal and Gambia). Int J Syst Evol Microbiol 50, 159-170.

Geniaux, E., Flores, M., Palacios, R. \& Martínez, E. (1995). Presence of megaplasmids in Rhizobium tropici and further evidence of differences between the two R. tropici subtypes. Int J Syst Bacteriol 45, 392-394.

Grange, L. \& Hungria, M. (2004). Genetic diversity of indigenous common bean (Phaseolus vulgaris) rhizobia in two Brazilian ecosystems. Soil Biol Biochem 36, 1389-1398.

Gu, C. T., Wang, E. T., Tian, C. F., Han, T. X., Chen, W. F., Sui, X. H. \& Chen, W. X. (2008). Rhizobium miluonense sp. nov., a symbiotic bacterium isolated from Lespedeza root nodules. Int J Syst Evol Microbiol 58, 1364-1368.

Guindon, S., Dufayard, J. F., Lefort, V., Anisimova, M., Hordijk, W. \& Gascuel, O. (2010). New algorithms and methods to estimate maximum-likelihood phylogenies: assessing the performance of PhyML 3.0. Syst Biol 59, 307-321.

Hall, T. A. (1999). BioEdit: a user-friendly biological sequence alignment editor and analysis program for Windows 95/98/NT. Nucleic Acids Symp Ser 41, 95-98.

Han, T. X., Wang, E. T., Wu, L. J., Chen, W. F., Gu, J. G., Gu, C. T., Tian, C. F. \& Chen, W. X. (2008). Rhizobium multihospitium sp. nov., isolated from multiple legume species native of Xinjiang, China. Int $J$ Syst Evol Microbiol 58, 1693-1699.

Harrison, P. W., Lower, R. P. J., Kim, N. K. D. \& Young, J. P. W. (2010). Introducing the bacterial 'chromid': not a chromosome, not a plasmid. Trends Microbiol 18, 141-148.

Hernández-Lucas, I., Rogel-Hernández, M. A., Segovia, L., RojasJiménez, K. \& Martínez-Romero, E. (2004). Phylogenetic relationships of rhizobia based on citrate synthase gene sequences. Syst Appl Microbiol 27, 703-706.

Hungria, M., Andrade, D. S., Chueire, L. M. O., Probanza, A., Guttierrez-Mañero, F. J. \& Megías, M. (2000). Isolation and characterization of new efficient and competitive bean (Phaseolus vulgaris L.) rhizobia from Brazil. Soil Biol Biochem 32, 1515-1528.

Hungria, M., Campo, R. \& Mendes, I. (2003). Benefits of inoculation of the common bean (Phaseolus vulgaris) crop with efficient and competitive Rhizobium tropici strains. Biol Fertil Soils 39, $88-93$.

Kaschuk, G., Hungria, M., Andrade, D. S. \& Campo, R. J. (2006). Genetic diversity of rhizobia associated with common bean (Phaseolus vulgaris L.) grown under no-tillage and conventional systems in Southern Brazil. Appl Soil Ecol 32, 210-220.

Martens, M., Delaere, M., Coopman, R., De Vos, P., Gillis, M. \& Willems, A. (2007). Multilocus sequence analysis of Ensifer and related taxa. Int J Syst Evol Microbiol 57, 489-503.

Martínez-Romero, E., Segovia, L., Mercante, F. M., Franco, A. A., Graham, P. \& Pardo, M. A. (1991). Rhizobium tropici, a novel species nodulating Phaseolus vulgaris L. beans and Leucaena sp. trees. Int J Syst Bacteriol 41, 417-426.

Mercante, F. M., Cunha, C. O., Straliotto, R., Ribeiro-Junior, W. Q., Vanderleyden, J. \& Franco, A. A. (1998). Leucaena leucocephala as a trap-host for Rhizobium tropici strains from the Brazilian "Cerrado" region. Rev Microbiol 29, 49-58. 
Moreira, A. P., Pereira, N., Jr \& Thompson, F. L. (2011). Usefulness of a real time PCR platform for GC content and DNA-DNA hybridization similarity estimations in vibrios. Int $J$ Syst Evol Microbiol 61, 2379-2383.

Musser, J. M., Bemis, D. A., Ishikawa, H. \& Selander, R. K. (1987). Clonal diversity and host distribution in Bordetella bronchiseptica. J Bacteriol 169, 2793-2803.

Pinto, F. G. S., Hungria, M. \& Martins Mercante, F. (2007). Polyphasic characterization of Brazilian Rhizobium tropici strains effective in fixing N2 with common bean (Phaseolus vulgaris L.). Soil Biol Biochem 39, 1851-1864.

Posada, D. (2008). jModelTest: phylogenetic model averaging. Mol Biol Evol 25, 1253-1256.

Ribeiro, R. A., Barcellos, F. G., Thompson, F. L. \& Hungria, M. (2009). Multilocus sequence analysis of Brazilian Rhizobium microsymbionts of common bean (Phaseolus vulgaris L.) reveals unexpected taxonomic diversity. Res Microbiol 160, 297-306.

Rincón-Rosales, R., Lloret, L., Ponce, E. \& Martínez-Romero, E. (2009). Rhizobia with different symbiotic efficiencies nodulate Acaciella angustissima in Mexico, including Sinorhizobium chiapanecum sp. nov. which has common symbiotic genes with Sinorhizobium mexicanum. FEMS Microbiol Ecol 67, 103-117.

Sawada, H. \& leki, H. (1992). Phenotypic characteristics of the genus Agrobacterium. Ann Phytopathol Soc Japan 58, 37-45.

Selander, R. K., McKinney, R. M., Whittam, T. S., Bibb, W. F., Brenner, D. J., Nolte, F. S. \& Pattison, P. E. (1985). Genetic structure of populations of Legionella pneumophila. J Bacteriol 163, 1021-1037.

Taboada, H., Encarnacion, S., Vargas, M. D. C., Mora, Y., MartinezRomero, E. \& Mora, J. (1996). Glutamine synthetase II constitutes a novel taxonomic marker in Rhizobium etli and other Rhizobium species. Int J Syst Bacteriol 46, 485-491.
Thompson, J. D., Gibson, T. J., Plewniak, F., Jeanmougin, F. \& Higgins, D. G. (1997). The CLUSTAL_X windows interface: flexible strategies for multiple sequence alignment aided by quality analysis tools. Nucleic Acids Res 25, 4876-4882.

Tighe, S. W., de Lajudie, P., Dipietro, K., Lindström, K., Nick, G. \& Jarvis, B. D. (2000). Analysis of cellular fatty acids and phenotypic relationships of Agrobacterium, Bradyrhizobium, Mesorhizobium, Rhizobium and Sinorhizobium species using the Sherlock Microbial Identification System. Int J Syst Evol Microbiol 50, 787-801.

Valverde, A., Igual, J. M., Peix, A., Cervantes, E. \& Velázquez, E. (2006). Rhizobium lusitanum sp. nov. a bacterium that nodulates Phaseolus vulgaris. Int J Syst Evol Microbiol 56, 2631-2637.

van Berkum, P., Navarro, R. B. \& Vargas, A. A. (1994). Classification of the uptake hydrogenase-positive (Hup +) bean rhizobia as Rhizobium tropici. Appl Environ Microbiol 60, 554-561.

Vandamme, P., Pot, B., Gillis, M., de Vos, P., Kersters, K. \& Swings, J. (1996). Polyphasic taxonomy, a consensus approach to bacterial systematics. Microbiol Rev 60, 407-438.

Velázquez, E., Palomo, J. L., Rivas, R., Guerra, H., Peix, A., Trujillo, M. E., García-Benavides, P., Mateos, P. F., Wabiko, H. \& MartínezMolina, E. (2010). Analysis of core genes supports the reclassification of strains Agrobacterium radiobacter K84 and Agrobacterium tumefaciens AKE10 into the species Rhizobium rhizogenes. Syst Appl Microbiol 33, 247-251.

Vincent, J. M. (1970). The cultivation, isolation and maintenance of rhizobia. In A Manual for the Practical Study of the Root-Nodule Bacteria, pp. 1-13. Edited by J. M. Vincent. Oxford: Blackwell Scientific.

Willems, A. \& Collins, M. D. (1993). Phylogenetic analysis of rhizobia and agrobacteria based on $16 \mathrm{~S}$ rRNA gene sequences. Int $J$ Syst Bacteriol 43, 305-313. 